\title{
Awareness about human papilloma virus vaccine among medical students
}

\author{
Snigdha Kamini', Devi Madhavi Bhimarasetty² \\ ${ }^{1}$ Final Year Part 2 MBBS Student, Andhra Medical College, Visakhapatnam - 2, Andhra Pradesh, India, \\ ${ }^{2}$ Professor and Head of the Department, Department of Community Medicine, Andhra Medical College, \\ Visakhapatnam-2, Andhra Pradesh, India
}

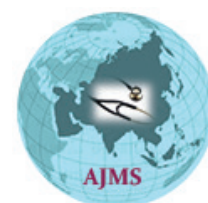

A B STRACT

Background: Human papilloma virus is a causative agent of cervical cancer. Hence,vaccination against HPV is an important mode of primary prevention against cervical cancer. Two vaccines against HPV have been approved and recommended for use in India. However the availability of these vaccines is hardly known and seldom utilised, even among the medical fraternity. Aims and Objectives: This study aims to find out the awareness about HPV vaccination among medical students of Andhra Medical College, India. Results of this study will help in assessing the need for awareness programs among health care professionals regarding this important public health issue. Materials and Methods: An observational descriptive study was conducted to know the awareness of HPV infection and vaccination among medical students of a government medical college at Visakhapatnam in Andhra Pradesh. A pretested questionnaire was administered to students of final MBBS Part 1 and final MBBS part 2. Results were analyzed in MS excel and the statistical significance of difference in knowledge between males and females was assessed. Results: Overall, the level of awareness reported was $54.5 \%$. Females had slightly better knowledge than males. Students of final year Part 2 had better knowledge the Final year part 1. The most commonly cited source of information was medical education and the most important factor that deterred subjects from receiving/ advising HPV vaccination was lack of knowledge. Conclusion: There exists a large gap in knowledge regarding HPV vaccination. Addressing this gap is necessary if we want to decrease the burden of cervical cancer in India. Medical students, health care providers should be sensitized first and then we should reach out to the public.

Key words: Cervical cancer, HPV vaccine, Awareness, Medical students
http://nepjol.info/index.php/AJMS DOI: 10.3126/ajms.v7i4.14613 E-ISSN: 2091-0576 P-ISSN: 2467-9100

\section{INTRODUCTION}

Cervical cancer is the second most common cancer in women in India, with an incidence of 20.1 per 10,000 population in 2014 and accounting for over 67,477 deaths annually. ${ }^{1}$ Underdeveloped and developing countries bear more than $80 \%$ of the global cervical cancer burden (WHO, 2010).

There has been definitive evidence to show that $70-80 \%$ cases of cervical cancers are due to persistent infection by the sexually transmitted Human Papilloma Virus types 16 and $18{ }^{2,3}$ Although condom use has been shown to be effective against HPV infection, lesions present in areas not covered by condoms may transmit the virus. ${ }^{4}$ The infection is asymptomatic most of the times, so the individual may not be aware that he is infected. Thus, vaccination is an important way of protecting against HPV. Vaccination against HPV is also an important mode of primary prevention against cervical cancer as it is one of those risk factors that can be prevented. ${ }^{5}$

Two types of recombinant vaccines against HPV have been approved for use in India, marketed as Gardasil and Cervarix. ${ }^{6}$ Though there have been concerns regarding the safety of these vaccines in India, The World Health Organization, Food and Drug Administration, Centre for Disease Control and Global Advisory Committee on 
Vaccine Safety have all confirmed and declared that the vaccine is safe and effective. ${ }^{7-9}$ The FUTURE trials have demonstrated an efficacy of $91-100 \% .{ }^{10}$

The HPV vaccine is recommended by the Indian Academy of Pediatrics and Federation of Obstetric and Gynecological Societies of India for all females who can afford the vaccine. ${ }^{6}$ Despite of this, the availability of the vaccine is hardly known and seldom utilized. There are a number of reasons for this, main reasons being lack of awareness-about the relationship of HPV with cervical cancer and about the availability of the vaccine, high costs and recent unproved controversies stating that these vaccines have had adverse side effects. ${ }^{11}$ This lack of awareness is a matter of concern as one of the ways by which we can decrease the burden of cervical cancer is by mass vaccination against HPV and mass screening programs. ${ }^{9} 12$

The success and benefit of any health program to control and prevent cervical cancer will depend to a great extent on the level of awareness of the potential beneficiaries as well as the caregivers about different basic aspects of the disease. Various studies have shown a very poor level of awareness regarding the HPV vaccine. ${ }^{11,13,14}$

For the public to be aware, it is essential that those in the medical field have a sound knowledge first. This includes health care professionals as well as medical students. In a few years these students will be practicing doctors and can play a pivotal role in spreading awareness among a wide range of population.

Very few studies have been done that document the levels of awareness among medical students. This study aims to analyze the awareness and acceptability of HPV vaccination among young medical students in the age group 18-23 belonging to Andhra Medical College, India. Results of this study will help in assessing the need for awareness programs among health care professionals about this important public health issue.

\section{MATERIALS AND METHODS}

An observational descriptive study was conducted to know the awareness of HPV infection and vaccination among medical students of a government medical college at Visakhapatnam in Andhra Pradesh.

Medical students of Andhra Medical College who are in final year part 1 and final year part 2 were the study population. The students who were present on that day were taken as study participants. Those who did not give consent were excluded from the study. The study was limited to one day and absentees were not administered questionnaires as there may be chance for bias. The students were assured of confidentiality of information and a pretested questionnaire was given after obtaining their consent. No time limit was given to complete the questionnaire.193 subjects were administered questionnaires out of which 19 questionnaires were excluded from the study as they were incomplete.

Data entry and analysis of results was done using Microsoft Excel. Study variables included gender, sources of information, knowledge about HPV vaccine and attitudes towards HPV vaccination.

\section{Statistical analysis}

Standard error of difference between proportions was applied to know the significance of difference in results between males and females. $p$ value of less than 0.05 was considered statistically significant.

The study was undertaken after approval from the Ethics Committee of Andhra Medical College, Visakhapatnam.

\section{RESULTS}

\section{Sociodemographic factors (Table 1)}

The study sample consisted of 174 medical students, belonging to Final year part 1 and final year part 2 . Their age ranged between 20-23 years and the mean age was 21.6.All of them were unmarried. Males formed $43.1 \%$ of study population and females $56.8 \%$.

\section{Knowledge about HPV infection (Tables 2 and 3)}

The correct mode of transmission of HPV was known by $79.3 \%$ of the study population. The other answers were droplet infection, parenteral infection, etc. A good percentage $(97.1 \%)$ of subjects knew that HPV could cause cervical cancer. However, only $40.2 \%$ knew the

\begin{tabular}{lcc}
\multicolumn{3}{c}{ Table 1: Sex distribution of study population } \\
\hline & Male & Female \\
\hline Part 1 & 41 & 53 \\
Part 2 & 34 & 46 \\
Total & 75 & 99 \\
\hline
\end{tabular}

\begin{tabular}{|c|c|c|c|}
\hline $\begin{array}{l}\text { Correct answer } \\
\text { regarding HPV infection }\end{array}$ & $\begin{array}{c}\text { Male } \\
(n=75) \\
(\%)\end{array}$ & $\begin{array}{c}\text { Female } \\
(n=99) \\
(\%)\end{array}$ & $\begin{array}{c}\text { Total } \\
(\mathrm{n}=174) \\
(\%)\end{array}$ \\
\hline $\begin{array}{l}\text { How is the HPV virus } \\
\text { transmitted? }\end{array}$ & $56(74.6)$ & $\begin{array}{l}82(82.8) \\
p>0.05\end{array}$ & $138(79.3)$ \\
\hline $\begin{array}{l}\text { Can the HPV virus cause } \\
\text { cervical cancer? }\end{array}$ & 71 (95.9) & $\begin{array}{c}98(98.9) \\
p>0.05\end{array}$ & $169(97.1)$ \\
\hline $\begin{array}{l}\text { What are the carcinogenic } \\
\text { strains of HPV? }\end{array}$ & $23(30.6)$ & $\begin{array}{l}47(47.4) \\
p<0.05\end{array}$ & $70(40.2)$ \\
\hline $\begin{array}{l}\text { What is the incidence of } \\
\text { cervical cancer in India? }\end{array}$ & $29(38.6)$ & $\begin{array}{c}40(40.4) \\
p>0.05\end{array}$ & 69 (39.6) \\
\hline
\end{tabular}




\begin{tabular}{|c|c|c|c|}
\hline Correct answer regarding HPV vaccination & Male $(n=75)(\%)$ & Female $(n=99)(\%)$ & Total $(n=174)(\%)$ \\
\hline Can cervical cancer be prevented by a vaccine? & $32(42.6)$ & $\begin{array}{c}63(63.6) \\
p>0.05\end{array}$ & $95(54.5)$ \\
\hline Is the HPV vaccine available in India? & $33(44)$ & $\begin{array}{c}61(61.6) \\
p<0.05\end{array}$ & $94(54)$ \\
\hline Is HPV vaccine part of a national program? & $31(41.3)$ & $\begin{array}{c}62(62.6) \\
p<0.05\end{array}$ & $93(53.4)$ \\
\hline Do women have to be tested before HPV vaccination? & $15(20)$ & $\begin{array}{c}40(40.4) \\
p<0.05\end{array}$ & $55(31.6)$ \\
\hline Can HPV vaccine be given to sexually active women? & $14(18.6)$ & $\begin{array}{c}38(38.3) \\
p<0.05\end{array}$ & $52(29.8)$ \\
\hline Do women who have been vaccinated & 40 (53.3), & $\begin{array}{c}48(48.4) \\
p>0.05\end{array}$ & $88(50.5)$ \\
\hline Does HPV protect against those already infected? & $36(48)$ & $\begin{array}{c}54(54.5) \\
p>0.05\end{array}$ & $90(51.7)$ \\
\hline Does HPV protect against other disease forms? & $14(18.6)$ & $\begin{array}{c}21(21.2) \\
p>0.05\end{array}$ & $35(20.1)$ \\
\hline Age group for vaccination & $28(37.3)$ & $\begin{array}{c}51(51.5) \\
p<0.05\end{array}$ & $79(45.4)$ \\
\hline Strains against which vaccine protects & $18(24.3)$ & $\begin{array}{c}30(30.3) \\
p>0.05\end{array}$ & $48(27.5)$ \\
\hline
\end{tabular}

carcinogenic strains. Only $39.6 \%$ of subjects knew the correct incidence of cervical cancer. Regarding other diseases caused by HPV, more than half of the subjects $(66 \%)$ mentioned that HPV infection could also cause anogenital warts and condyloma acuminata. Only 19 subjects mentioned that it could cause Penile carcinoma and 11 mentioned Anal carcinoma.

More percentage of females answered correctly, and the difference in knowledge of carcinogenic strains between females and males was statistically significant. Part 2 students had better knowledge than part 1 students.

Nearly $1 / 3^{\text {rd }}$ of the study population was not aware of the presence of a vaccine for HPV. Females $(74.7 \%)$ were more aware of the HPV vaccine than males (58.6\%).

\section{Attitude towards HPV vaccination}

None of the study subjects had ever taken the HPV vaccine. Of all the subjects, $64.9 \%$ were willing to receive/ advice HPV vaccination. The others were either unsure or unwilling. $80.8 \%$ of females were willing to receive vaccination while only $44 \%$ of males were willing to advice it to women. The most important factor that deterred the subjects from receiving/advising HPV vaccination was lack of enough knowledge, followed by high cost and then fear of complications. The most important source of knowledge was Medical education. Only one subject mentioned doctor's advice as source of information.

\section{DISCUSSION}

Majority of the students were well aware of the viral etiology of cervical cancer.
However, the preventable nature of cervical cancer was known by only half of students $(54.5 \%)$. This is lesser than the results reported by S.Mehta et al and D.Pandey et $\mathrm{al}^{15,16}$ whose studies have been in medical students in Other Indian medical colleges. The study also reported a lower level of awareness than studies done among doctors in Bangalore. ${ }^{17}$ The level of awareness regarding HPV vaccination was, however higher than those studies done among general population and among nurses by Swapnajaswanth et al, Ramavath et al and Siddharthar J et al..$^{13,14,17}$ The difference in study subjects or difference in study setting may be a reason for these differences. Final year part 2 students had better knowledge that final year part 1. This shows that medical education curriculum does play a role in spreading awareness.

Overall, a higher level of awareness were found among female subjects than male subjects, and this is consistent with the findings observed by S Mehta et al and D. Pandey et al. ${ }^{15,16}$ This may be because the causal relationship between HPV and cervical cancer is more well known than its causal relationship with other cancers like penile cancer and anal cancer, causing females to be more aware.

S Mehta et al reported that $66.8 \%$ were willing to accept the HPV vaccine, ${ }^{15}$ our findings $(64 \%)$ come close to this. Females were more willing to accept vaccination.Majority of students said that lack of adequate knowledge was the most important factor preventing them from getting vaccinated. This is consistent with several other studies in India, another main reason being high cost.

\section{Limitation of the study}

The limitation of this study was that only final year medical students were included. 


\section{CONCLUSION}

The study reports that about half of the students are aware of HPV vaccination. Hence, a still lower level of awareness may be expected among the lay public. This clearly demonstrates the gap in knowledge. Overcoming this gap is necessary if we want to decrease the burden of cervical cancer in India. The information must be included early in the medical education curriculum and reinforced thereafter. It is necessary to implement health education programs, group discussions and forums where aspects of HPV infection, its association with cervical cancer, and the HPV vaccine are clearly highlighted and doubts clarified.

There is an urgent need for further sensitization of people, both in the health care sector and general public regarding $\mathrm{HPV}$ and $\mathrm{HPV}$ vaccination.

\section{REFERENCES}

1. Human Papillomavirus and related Diseases Report [online] Available from: URL: www.hpvcentre.net/statistics/reports/XWX. pdf

2. Castellsagué $X$. Natural history and epidemiology of HPV infection and cervical cancer. Gynecologic oncology 2008; 110(3): S4-S7.

3. Schiffman M, Castle PE, Jeronimo J, Rodriguez AC and Wacholder S. Human papillomavirus and cervical cancer. The Lancet 2007; 370(9590): 890-907.

4. Manhart LE and Koutsky LA. Do condoms prevent genital HPV infection, external genital warts, or cervical neoplasia? A metaanalysis. Sexually transmitted diseases 2002; 29(11): 725-735.

5. Thun MJ, DeLancey JO, Center MM, Jemal A and Ward EM. The global burden of cancer: priorities for prevention. Carcinogenesis 2010; 31(1): 100-110.

6. Indian Academy of Pediatrics Committee on Immunization IAPCOI.Consensus recommendations on immunization, 2008. Indian Pediatrics 2008; 45(8):635.

7. Kash N, Lee MA, Kollipara R, Downing C, Guidry J and Tyring SK. Safety and Efficacy Data on Vaccines and Immunization to
Human Papillomavirus. Journal of Clinical Medicine 2015; 4(4): 614-633.

8. Nakalembe M, Mirembe FM and Banura C. Vaccines against human papillomavirus in low and middle income countries: a review of safety, immunogenicity and efficacy. Infectious agents and cancer 2015; 10(1): 17.

9. Basu P, Banerjee D, Singh P, Bhattacharya C and Biswas J. Efficacy and safety of human papillomavirus vaccine for primary prevention of cervical cancer: A review of evidence from phase III trials and national programs. South Asian journal of cancer 2013; 2(4):187.

10. Future II Study Group. Prophylactic efficacy of a quadrivalent human papillomavirus (HPV) vaccine in women with virological evidence of HPV infection. Journal of Infectious Diseases 2007; 196(10): 1438-1446.

11. Montgomery MP, Dune T, Shetty PK and Shetty AK. Knowledge and Acceptability of Human Papillomavirus Vaccination and Cervical Cancer Screening among Women in Karnataka, India. Journal of Cancer Education 2015; 30(1): 130-137.

12. Diaz M, Kim JJ, Albero G, De Sanjosé S, Clifford G, Bosch FX and Goldie SJ. Health and economic impact of HPV 16 and 18 vaccination and cervical cancer screening in India. British journal of cancer 2008; 99(2): 230-238.

13. Ramavath KK and Olyai R. Knowledge and Awareness of HPV Infection and Vaccination Among Urban Adolescents in India: A Cross-Sectional Study. The Journal of Obstetrics and Gynecology of India 2013; 63(6): 399-404.

14. Siddharthar J, Rajkumar B and Deivasigamani K. Knowledge, Awareness and Prevention of Cervical Cancer among Women Attending a Tertiary Care Hospital in Puducherry, India. Journal of clinical and diagnostic research: JCDR 2014; 8(6): OC01.

15. Mehta S, Rajaram S, Goel G and Goel N. Awareness about Human Papilloma Virus and its vaccine among medical students. Indian journal of community medicine: official publication of Indian Association of Preventive \& Social Medicine 2013; 38(2): 92.

16. Pandey D, Vanya V, Bhagat S and Shetty J. Awareness and attitude towards human papillomavirus (HPV) vaccine among medical students in a premier medical school in India. PloS one 2012; 7(7): e40619.

17. Swapnajaswanth $M$, Suman G, Suryanarayana $S$ and Murthy N. Perception and Practices on Screening and Vaccination for Carcinoma Cervix among Female Healthcare Professional in Tertiary Care Hospitals in Bangalore, India. Asian Pacific journal of cancer prevention: APJCP 2013; 15(15): 6095-6098.

\section{Authors Contribution:}

SK - Concept and design of study, literature search, data collection, statistical analysis, preparation of first draft of manuscript; DMB - Concept and design of the study, reviewed the literature, manuscript preparation and critical revision of the manuscript.

Source of Support: Nil. Conflict of Interest: None. 